\title{
The Purification of the Extracellular Acid Protease of Rhodotorula glutinis K-24 and Its General Properties ${ }^{\dagger}$
}

\author{
By Masahiro Kamada, * Kohei Oda and Sawao Murao \\ Department of Agricultural Chemistry, College of Agriculture, \\ University of Osaka Prefecture \\ Received October 18, 1971
}

\begin{abstract}
The acid protease produced from Rhodotorula glutinis K-24 was purified and crystallized by precipitation with ammonium sulfate, fractional precipitation with acetone, gel-filtration with Sephadex G-100, and $\mathrm{pH}$ adjustment. The recovery of activity was about 40 per cent, and about $80 \sim 100 \mathrm{mg}$ of third crystallized enzyme was obtained from one liter of broth. The purified enzyme was chromatographically homogeneous and confirmed to be monodispersive by physicochemical criteria. The enzyme was most active at $\mathrm{pH}$ values between 2.0 and 2.5 toward casein, and was stable at $\mathrm{pH}$ values from 2.5 to 6.5 on twenty hour incubation at $37^{\circ} \mathrm{C}$. Comparing with several proteases obtained from various sources, the specific activity toward casein was potent and was 1.7 times that of pepsin. The enzyme was inactivated by pepsin inhibitor (S-PI) produced from streptomyces naniwaensis, wheares it was not inactivated by SLS, divalent metal ions and sulfhydryl reagents.
\end{abstract}

Many kinds of molds have been known to produce a variety of acid proteases and some of these proteases were purified. ${ }^{1 \sim 6}$ !

Little is known, however, on the extracellular protease of yeasts, although Candida albicans of yeast was revealed to be producer of protease. ${ }^{7}$ In the previous paper, ${ }^{81}$ it was reported that during screening tests for extracellular protease of yeasts, a potent extracellular acid protease producing yeast was isolated from grape farm soil and was identified as Rhodotorula glutinis (Fres.) Harrison.

The enzyme was produced with high productivity on a synthetic medium. The present paper deals with studies on purification and general properties of the purified acid protease.

$\uparrow$ Studies on the Extracellular Protease of Yeasts. Part III. See reference. ${ }^{8}$ The report was presented at the Annual Meeting of the Agricultural Chemical Society of Japan at Fukuoka City, April, 1970.

* Present address; Central Research Laboratory of Ajinomoto Co., Ltd., Suzukicho, Kawasaki City.

\section{MATERIALS AND METHODS}

1. Microorganism and culture method. Rhodotorula glutinis K-24 isolated from grape farm soil was used through out of this study. For the acid protease production, the following synthetic medium was employed: Glucose 7\%, Polypeptone 2\%, $\mathrm{KH}_{2} \mathrm{PO}_{4}$ $0.6,0, \mathrm{MgSO}_{4} \cdot 7 \mathrm{H}_{2} \mathrm{O} \quad 0.08, \%, \mathrm{MnSO}_{4} \cdot 6 \mathrm{H}_{2} \mathrm{O} 4 \mathrm{ppm}$, $\mathrm{FeSO}_{4} \cdot 7 \mathrm{H}_{2} \mathrm{O} 4 \mathrm{ppm}$, Thiamine $2 \mathrm{ppm}, \mathrm{pH} 2.8$.

R. glutinis $\mathrm{K}-24$ was cultured under shaking by ordinary method at $25^{\circ} \mathrm{C}$ for 3 days.

2. Assay of protease activity. The protease activity was measured as follows. To $3 \mathrm{ml}, 4 / 3, \%$ milk casein solution containing $0.05 \mathrm{M}$ lactate buffer at $\mathrm{pH} 2.5$ was added $1 \mathrm{ml}$ of enzyme solution at $37^{\circ} \mathrm{C}$. After incubation for ten minutes, the reaction was stopped by an addition of $4 \mathrm{ml}$ of $0.44 \mathrm{M}$ trichloroacetic acid, followed by filtration.

One $\mathrm{ml}$ of the filtrate was mixed with $5 \mathrm{ml}$ of $0.44 \mathrm{M}$ $\mathrm{Na}_{2} \mathrm{CO}_{3}$ and $1 \mathrm{ml}$ of the Folin-Ciocalteu reagent was added to it. The optical density of the color developed was measured at $660 \mathrm{~m} \mu$. A unit of enzyme activity was defined as the enzyme quantity which liberate $1, \mathrm{~g}$ of tyrosine per $\mathrm{ml}$ of the reaction mixture per minute under the conditions. The specific 
activity (units/mg protein) was also measured according to the assay method by Fukumoto et al ${ }^{4}$

3. Other proteolytic enzyme used. For comparison, several proteolytic enzymes were used in the present experiment. Recrystallized pepsin was a product of Washington Biochemical Co., Ltd. Crystallized preparations of acid proteases of Rhizopus chinensis acid protease, ${ }^{4}$ Mucos pusillus rennin protease ${ }^{5}$ and Trametes sanguinea acid protease $^{3}$ ) were kindly donated from Dr. D. Tsuru of Osaka City University, Dr. S. Iwasaki of Meitosangyo Co. Ltd., Dr. $K$. Tomoda of Takeda Chemical Industries, respectively.

Partially purified preparation of Aspergillus saitoi acid protease was purchased from lashima drug Co., Ltd., and used after further purification by Ichishima's method.9,10) Cladosporium acid protease was purified as reported previously. ${ }^{11}$

4. Ultracentrifugal analysis. Ultracentrifugal studies were preformed with a Spinco Model E ultracentrifuge equipped with a schlieren cylindrical lens system.

5. Electrophoresis. Electrophoretic experiment was carried out in a Hitachi HTB-2 Tiselius-Type electrophoresis apparatus. Disc electrophoresis was also conducted with a $7.5 \%$ polyacrylamide gel column at $\mathrm{pH}$ 9.5.

\section{RESULTS AND DISCL'SSION}

\section{Purification and crystallization of $R$. glutinis} $K-24$ acid protease

The enzyme purification and crystallization were carried out as follows. After removing the cells of 5 liters cultured broth $(\mathrm{pH} \mathrm{1.8)}$ by the centrifugation at $10,000 \mathrm{rpm}$ for $10 \mathrm{~min}$, about $3.0 \mathrm{~kg}$ ammonium sulfate ( 0.8 satulation) were added to the culture solution, then stored at $3 \sim 5 \mathrm{C}$ for $1 \sim 2$ days.

The precipitate was seperated from supernatant by centrifugation and dissolved immediately in about $100 \mathrm{ml} 10^{-2} \mathrm{M}$ sodium citrate buffer, $\mathrm{pH}$ 4.0. After dissolved $2 \mathrm{~g}$ sodium chloride to the enzyme solution, cold aceton was added to the enzyme solution to a final concentration of 55 vol $\%$ and the mixture was allowed to stand overnight at $0 \sim 2^{\circ} \mathrm{C}$.
The resulting precipitate was removed by centrifugation at $16,000 \mathrm{rpm}$ for ten minutes in order to remove polysaccharides and other impurities. Cold aceton was added to the supernatant untill about 75 vol $\%$, then stored

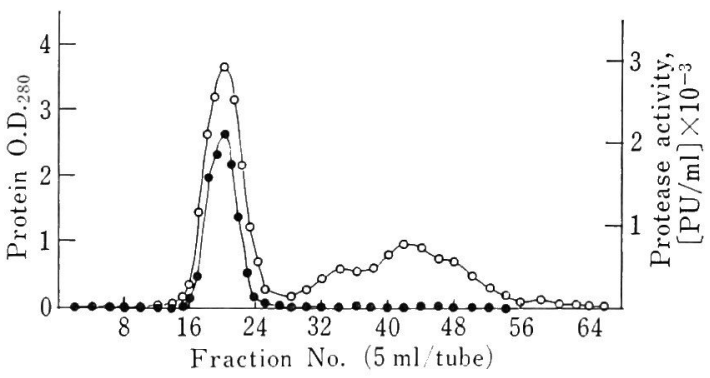

FIG. 1. Column Chromatogram of Partially Purified Enzyme on Sephadex G-100.

Partially purified enzyme was loaded on a column $(2.5 \times 36 \mathrm{~cm})$ which was equilibrated with $10^{-2} \mathrm{M}$ sodium citrate buffer, $\mathrm{pH}$ 4.0. Flow rate was 10 $\mathrm{ml} / \mathrm{hr}$. See the text for the experimental details.

O-O: Protein, O.D.280,

- - Protease activity $(\mathrm{PU} / \mathrm{ml})$.

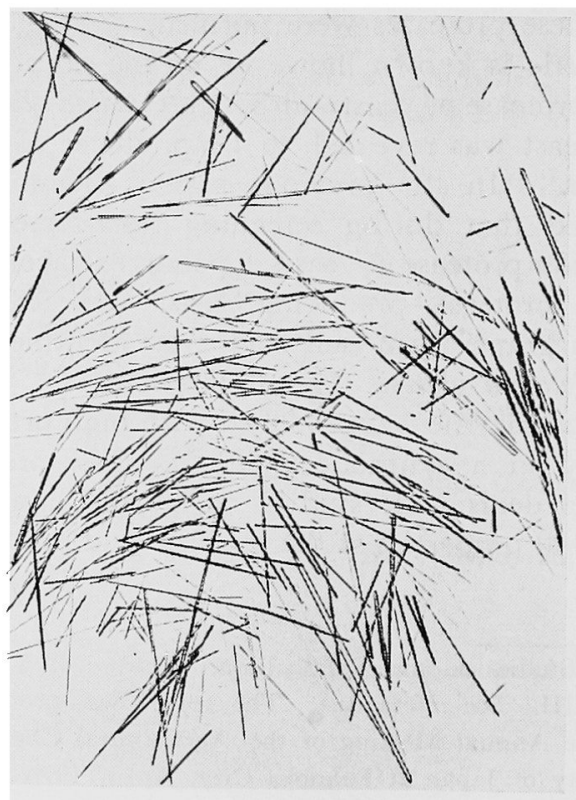

FIG. 2. Micrograph of Crystalline Acid Protease of Rhodotorula glutinis K-24. 
Table I. Purification of Acid Protease of Rhodotorula glutinis K-24

\begin{tabular}{|c|c|c|c|c|}
\hline Procedure & Vol. & $\begin{array}{l}\text { Activity } \\
\text { (PU/ml) } \\
\times 10^{-3}\end{array}$ & $\begin{array}{l}\text { Specific activity } \\
\left.\text { (PU,O.D. } 280 \mathrm{~m}^{\prime \prime}\right)\end{array}$ & $\begin{array}{l}\text { lield } \\
(0)\end{array}$ \\
\hline Culture broth & 5000 & 0.32 & 56 & 100 \\
\hline \multicolumn{5}{|l|}{$\left(\mathrm{NH}_{4}\right)_{2} \mathrm{SO}_{4}$ pptn } \\
\hline Supernatant & 100 & 14.7 & 136 & 92 \\
\hline \multicolumn{5}{|c|}{$\begin{array}{l}\text { Fractionation by acetone } \\
\text { Chromatography on Sephadex }\end{array}$} \\
\hline Eluate & 40 & 24.0 & 760 & 60 \\
\hline Acetone pptn & & & & \\
\hline Supernatant & 10 & 88.0 & 800 & 55 \\
\hline $\mathrm{pH}$ adjustment (pH 4.5) & & & & \\
\hline \multicolumn{2}{|l|}{ Crystals } & & 880 & 48 \\
\hline Recrystallization & & & & \\
\hline \multicolumn{2}{|l|}{ Freeze-dried preparation } & & 1040 & 40 \\
\hline
\end{tabular}

at $0^{\circ} \mathrm{C}$ for $2 \sim 3 \mathrm{hr}$. The precipitate was collected by a centrifugation, dissolved with 10 $\mathrm{ml} 10^{-2} \mathrm{M}$ sodium citrate buffer, $\mathrm{pH} 4.0$, and chromatographed on a column of Sephadex G-100 equilibrated with the buffer solution.

The representative chromatographic pattern is shown in Fig. 1.

The active fractions were combined and cold aceton was added to the solution untill 75 volos. The precipitate was collected by centrifugation at $16,000 \mathrm{rpm}$ for 10 minutes, dissolved in a minimum amounts (about $7 \sim 10 \mathrm{ml}$ ) of $10^{-2} \mathrm{M}$ sodium citrate buffer, $\mathrm{pH} 4.0$, and then adjusted the $\mathrm{pH}$ to 4.5 with $1 \mathrm{M}$ sodium citrate solution. The enzyme solution was left at $2 \sim 5^{\circ} \mathrm{C}$. Needle like crystals appeared within $2 \mathrm{hr}$ and crystallization was completed after overnight storage at $2 \sim 5^{\circ} \mathrm{C}$. The crystals were collected using a centrifuge and dissolved by $10^{-2} \mathrm{M}$ sodium citrate buffer, $\mathrm{pH} 2.5 \sim 4.0$, at room temperature.

After removing insoluble materials, if present, by centrifugation, the protease solution was adjusted to $\mathrm{pH} 4.5$ with sodium citrate and stored in refrigerator. Needle like crystals were obtained in overnight storage. The crystallization method was repeated once more. In Fig. 2, microphotograph of crystalline en- zyme preparation was presented. The purified enzyme was dissolved in distilled water and lyophilized. About $450 \mathrm{mg}$ preparation was obtained from 5 liters cultured broth. The flow sheet of purification procedure was summarized in Table I.

\section{Homogeneity of the enzyme preparation}

Homogeneity of the enzyme was checked using the lyophilized preparation.

1. SE(sulfoethyl)-Sephadex C-50 chromatography. Homogeneity of the enzyme was checked by chromatography on a SE-Sephadex C-50 column equilibrated with $10^{-2} \mathrm{M}$ sodium citrate buffer, $\mathrm{pH} 4.0$, and a single symmetrical peak with specific activity 1,100 was found on a linear gradient elution system with sodium chloride as shown in Fig. 3.

\section{Ultracentrifugal analysis. Ultracentrifugal} pattern of the enzyme was obtained as Fig. 4, the preparation was also homogeneous.

3. Electrophoretic analysis. The schlieren diagrams of the ascending and descending boundaries in an electrophresis at $\mathrm{pH} 2.0,4.0$ and 6.0 are shown in Fig. 5. The photographs 


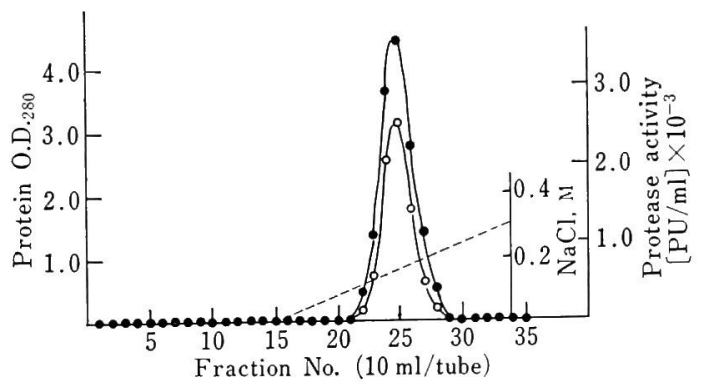

FIG. 3. Column Chromatogram of Acid Protease on SE-Sephadex C-50.

Lyophilized preparation was applied on a column $(1.5 \times 97 \mathrm{~cm})$ which was equilibrated with $10^{-2} \mathrm{M}$ sodium citrate buffer, $\mathrm{pH} 4.0$. After washing the column with the same buffer described above, the protease was eluted with linear gradient increase in $\mathrm{NaCl}$ concentration at a flow rate of $9 \mathrm{ml} / \mathrm{hr}$.

O-O: Protein, O.D.280,

-1): Protease activity $(\mathrm{PU} / \mathrm{ml})$. were taken at an interval of $120 \mathrm{~min}$ with a current $7.5 \mathrm{~mA}$. As shown in Fig. 5, the preparation was electrophoretically homogeneous at $\mathrm{pH} 2.0$ and 4.0, but at $\mathrm{pH} 6.0$, a few heterogeneity was observed. This heterogeneity probably arose mainly from autolysis during dialysis and electrophoresis.

To check this result, disc electrophoresis was further carried out at $\mathrm{pH}$ 9.5. As shown in Fig. 6, a single band appeared on acrylamide disc electrophoresis, which suggests that the preparation is homogeneous.

\section{Properties of the purified enzyme}

1. Effect of $p H$ on activity and stability of the enzyme. The protease was most active at $\mathrm{pH}$ values between 2.0 and 2.5 toward casein, between 2.5 and 3.0 toward acid denatured

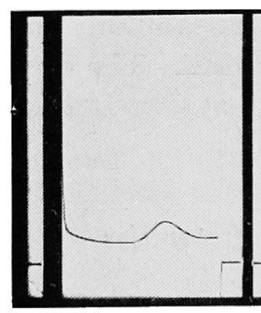

$75 \mathrm{~min}$

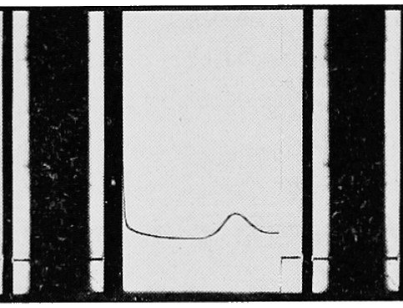

$60 \mathrm{~min}$

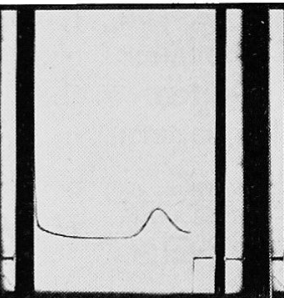

$45 \mathrm{~min}$

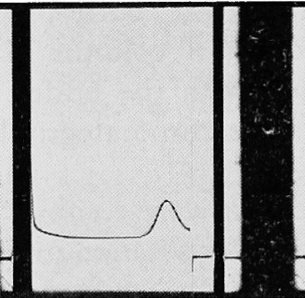

$30 \mathrm{~min}$

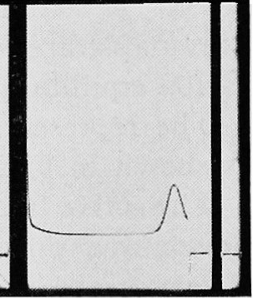

$15 \mathrm{~min}$

FIG. 4. Sedimentation Patterns of Acid Protease.

The enzyme concentration was about $10^{\circ}$ in $10^{-1} \mathrm{M}$ sodium citrate buffer, $\mathrm{pH} 4.0$, containing $\mathrm{NaCl}(u=0.1)$. Temperature was $25^{\circ} \mathrm{C}$. The photographs were taken at indicated times reachings after full speed $(56,000 \mathrm{rpm})$.

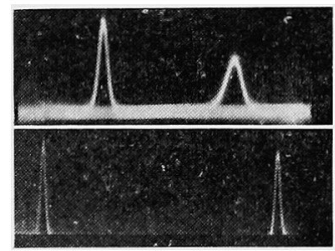

$\mathrm{pH} 2.0$

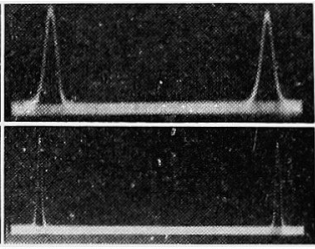

$\mathrm{pH} 4.0$

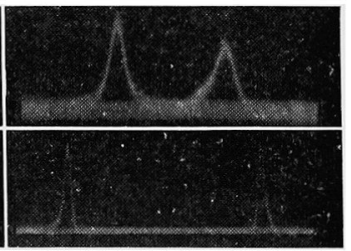

pH 6.0
$120 \mathrm{~min}$

$0 \min$

FIG. 5. Electrophoretic Pattern of Acid Protease.

The electrophoretic migration was carried out in $10^{-1} \mathrm{M}$ sodium citrate buffer of $\mathrm{pH} 2.0$, 4.0 and in McIlvaine buffer of $\mathrm{pH}$ 6.0. The ionic strength of the buffer solution was 0.1 . The current was $7.5 \mathrm{~mA}$ at $4{ }^{\circ} \mathrm{C}$. The ascending and decending boundaries are shown $120 \mathrm{~min}$ after the start of electrophoresis. 
hemoglobin and was stable over the range 2.0 to 6.5 on a twenty hour incubation at $37^{\circ} \mathrm{C}$ as shown in Fig. 7 and Fig. 8.

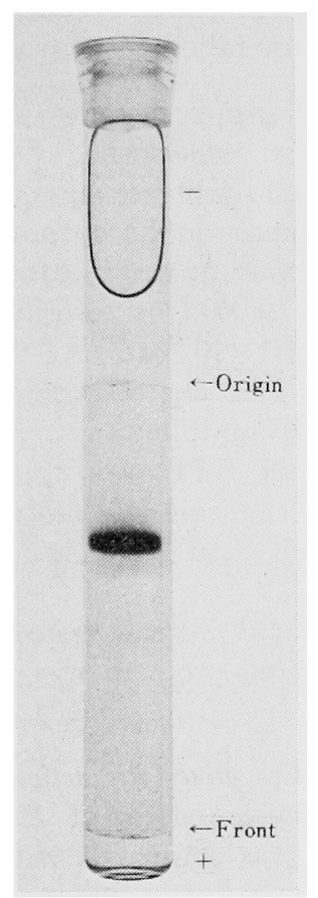

FIG. 6. Polyacrylamide Disc Gel-electrophoresis of Purified Enzyme at $\mathrm{pH}$ 9.5.

Approximately $200 \mu \mathrm{g}$ of protein was applied on a column $(0.5 \times 5 \mathrm{~cm})$ and electrophoresis was carried out at $2 \mathrm{~mA}$ per column at $5^{\circ} \mathrm{C}$ for $2 \mathrm{hr}$.

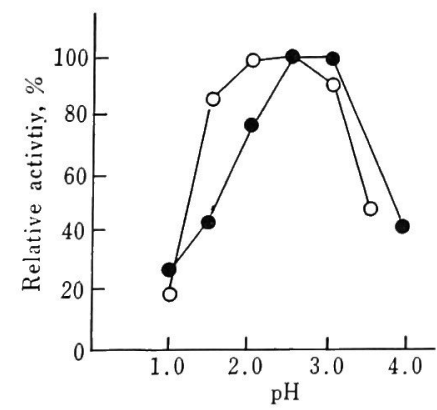

FIG. 7. Effect of $\mathrm{pH}$ on Protease Activity.

Casein and hemoglobin were dissolved in $10^{-1} \mathrm{M}$ sodium citrate buffer of various $\mathrm{pH}$ values.

○- $\mathrm{O}$ : Casein,

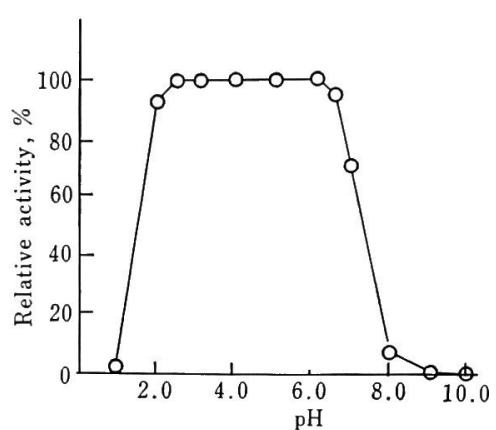

FIG. 8. Effect of $\mathrm{pH}$ on the Stability of Acid Protease.

Enzymes were incubated at each $\mathrm{pH}$ for $20 \mathrm{hr}$ at $37^{\circ} \mathrm{C}$ and the remaining activities were assayed at $\mathrm{pH} 2.5$.

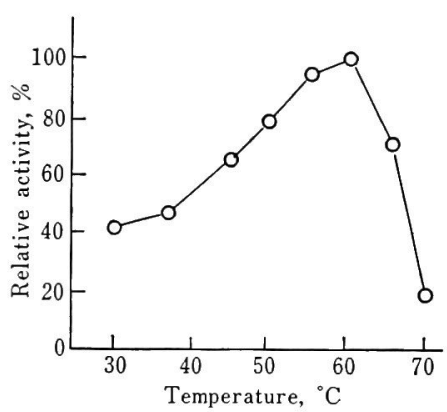

FIG. 9. Effect of Temperature on Enzyme Reaction.

The reaction was carried out for $10 \mathrm{~min}$ at various temperatures.

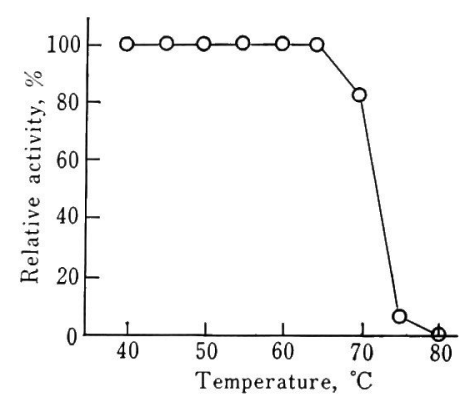

FIG. 10. Thermal Stability of Acid Protease.

Enzymes were incubated at each temperature for $10 \mathrm{~min}$ at $\mathrm{pH} 4.0$ and the remaining activities were assayed at $37^{\circ} \mathrm{C}$. 
2. Temperature optimum of the enzyme reaction and thermal stability. The enzyme reaction was carried out at various temperature, at $\mathrm{pH}$ 2.5 for $10 \mathrm{~min}$. The optimum temperature for casein was about $60^{\circ} \mathrm{C}$ as shown in Fig. 9 . The enzyme dissolved in $10^{-2} \mathrm{M}$ citrate buffer solution, $\mathrm{pH} 4.0$ was incubated at various temperatures for $10 \mathrm{~min}$ and the remaining activity was assayed at $37^{\circ} \mathrm{C}$. The results shown in Fig. 10 indicated that this enzyme was stable at temperature below $65^{\circ} \mathrm{C}$ and about $80 \%$ activity remained even at $70^{\circ} \mathrm{C}$.

3. Influence of metal ions and other chemicals. Effects of several metal ions and other chemical reagents on the protease activity were examined. Various metal ions, EDTA(ethylenediaminetetra acetic acid sodium salt) and sulfhydryl reagents such as $p$-chloromercuribenzoate and monoiodo acetic acid did not inhibit the acid protease produced from $R$. glutinis K-24. Even SLS (sodium lauryl sulfate) which completely inactivate the mold acid proteases, did not inhibit (Table II).

Table II. EFFeCt of Vartous Reagents on ENZYME ACTIVITY

The enzyme, $10 \mathrm{~kg} / \mathrm{ml}$, was incubated at $37^{\circ} \mathrm{C}$ for 15 min with various chemicals at $\mathrm{pH} 4.0$ or 6.0 , and then the remaining activity was assayed at $\mathrm{pH} 2.5$.

\begin{tabular}{lcc}
\hline Chemicals & $\begin{array}{c}\text { Concentration } \\
(\mathrm{mM})\end{array}$ & $\begin{array}{c}\text { Remaining } \\
\text { activity }\left(\mathrm{C}_{0}\right)\end{array}$ \\
\hline $\mathrm{None}$ & - & 100 \\
$\mathrm{HgCl}_{2}$ & 1.0 & 100 \\
$\mathrm{PbCl}_{2}$ & 10.0 & 100 \\
$\mathrm{ZnCl}_{2}$ & 10.0 & 100 \\
$\mathrm{NgCl}_{2}$ & 10.0 & 100 \\
$\mathrm{CuCl}_{2}$ & 10.0 & 100 \\
$\mathrm{FeCl}_{2}$ & 1.0 & 97 \\
$\mathrm{NCl}_{2}$ & 10.0 & 100 \\
$\mathrm{CoCl}_{2}$ & 10.0 & 100 \\
$\mathrm{IAA}$ & 10.0 & 100 \\
EDTA (pH 6) & 10.0 & 100 \\
$\mathrm{PCMB}(\mathrm{pH} 6)$ & 1.0 & 100 \\
$\mathrm{SLS}$ & 1.0 & 100 \\
\hline
\end{tabular}

IA: Monoiodo acetic acid, EDTA: Ethylendiaminetetraacetic acid sodium salt. PCMB: $p$-Chloromercuribenzoate, SLS: Sodium lauryl sulfate.
E. Ichishima and F. Yoshida ${ }^{121}$ reported that conformation of Aspergillopeptidase A was apparently converted by sodium lauryl sulfate, into a partially $\alpha$-helical conformation and the residual activity falled to zero $\left(1 \sim 5 \times 10^{-3} \mathrm{M}\right)$.

4. Effect of pepsin inhibitor (S-PI) produced from Streptomyces naniwaensis. ${ }^{13} \quad$ Effect of S-PI on $R$. glutinis acid protease was compared with other acid protease at its optimum $\mathrm{pH}$. One $\mathrm{mg}$ of $R$. glutinis acid protease $\left(3.3 \times 10^{-8} \mathrm{M}\right)$ was inhibited by 60,0 of original activity at $20 \mu \mathrm{g}$ of S-PI $\left(3.1 \times 10^{-8} \mathrm{M}\right)$. At this concentration of S-PI, one $\mathrm{mg}$ of pepsin $\left(2.9 ; 10^{-8} \mathrm{M}\right)$ was completely inhibited.

The effect of S-PI was specific on acid protease and the rate of inhibition was different on each acid proteases as shown in Table III.

Among the acid protease tested, Cladosporium sp. No. 45-2 acid protease was most resistant toward S-PI.

5. Comparative proteolytic activity. The proteolytic activity on casein of $R$. glutinis K-24 acid protease was compared with several acid

\section{TABLE III. EFFECT OF Streptomyces-PEPSIN INHIBITOR (S-PI) ON VARIOUS ACID PROTEASES}

The enzyme, $1 \mathrm{mg} / \mathrm{ml}$, was incubated at $37^{\circ} \mathrm{C}$ for $10 \mathrm{~min}$ with equal volume of S-PI solution at optimum $\mathrm{pH}$ and then the remaining activity was assayed.

\begin{tabular}{lrc} 
Protense & $\begin{array}{c}\text { Concen- } \\
\text { tration } \\
(\mu g)\end{array}$ & $\begin{array}{c}\text { Remaining } \\
\text { activity } \\
(00)\end{array}$ \\
\hline Rhodotorula glutinis & 20 & 40 \\
K-24 acid & 10,000 & 0 \\
Cladosporium sp. & 20 & 80 \\
No. 45-2 acid & 1,000 & 0 \\
Pepsin & 20 & 0 \\
Trametes sanguinea acid & 10,000 & 0 \\
Rhizopus chinensis acid & 20 & 65 \\
& 10,000 & 0 \\
Aspergillus saitoi acida & 10,000 & 42 \\
& 20 & 0 \\
& 10,000 & 55 \\
\end{tabular}

a) Partially purified preparation. 
proteases obtained from various sources. The proteolytic activity of $R$. glutinis K-24 acid protease was shown to be most potent enzyme among these of acid proteases (Table IV).

\section{Table IV. Proteolytic Activity of Several Proteases}

\begin{tabular}{lc} 
Protease & $\begin{array}{c}\text { Specific activity } \\
\text { (PU,mg protein) } \\
\text { at optimal pH }\end{array}$ \\
\hline Rhodotorula glutinis $\mathrm{K}-2+$ acid & 5,200 \\
Cladosporium sp. No. $45-2$ acid & 3,400 \\
Pepsin & 3,000 \\
Rhiropus chinensis acid & 2,200 \\
Aspergillus saitoi acidas & 2,000 \\
Trametes sanguinea acid & 2,200
\end{tabular}

a) This datum was quated from the paper of $\mathrm{J}$. Fukumoto, D. Tsuru and T. Yamamoto.

Acknowledgement. The authors wish to express their sincere thanks to Dr. M. Arai, Mr. S. Satoi, Department of Agricultural Chemistry, University of Osaka Prefecture, for their valuable advice.

\section{REFERENCES}

1) F. Yoshida, Bull. Agr. Chem. Soc. Japan, 20, 252 (1956).

2) J. Sawada, Agr. Biol. Chem., 27, 677 (1963).

3) K. Tomoda and H. Shimazono, ibid, 28, 770 (1964).

4) J. Fukumoto, D. Tsuru and T. Jamamoto, ibid., 31, 710 (1967); ibid., 33, 1419 (1969).

5) K. Arima, S. Iwasaki and G. Tamura, Appl. Microbiol., 16, 1727 (1968).

6) S. Yoshimura, T. Kishida and G. Danno, Nippon Nogeikagaku Kaishi, 38, 128 (1964).

7) H. Remold, H. Fasold and F. Staib, Biochim. Biophys. Acta, 167, 399 (1968).

8) S. Murao, M. Kamada, T. Nakaze, S. Ogura and K. Oda, Nippon Nogeikagaku Kaishi, 46, 167 (1972).

9) E. Ichishima and F. Yoshida, Biochem. Biophys. Acta, 99, 360 (1965).

10) E. Ichishima, "Method in Enzymology," Vol. XIX, ed. by G.E. Perlmann and L. Lorand, Academic Press Inc., New York, 1970, p. 397.

11) S. Murao, S. Funakoshi and K. Oda, Agr. Biol. Chem., in press.

12) E. Ichishima and F. Ioshida, Biochim. Biophys. Acta, 147, 341 (1967).

13) S. Murao and S. Satoi, Agr. Biol. Chem., 34, 1265 $(1970)$. 